Original

\title{
Prevalence of Candida Carriage in Healthy Oral Cavity
}

\author{
Yoshikazu UmeZAwA, Kazunori NiNOMIYA, and Izumi MATAGA
}

\begin{abstract}
Even though Candida is one of the oral flora, the prevalence in healthy young subjects without oral disorder has not completed yet. Based on this situation, the aim of this study was to examine the oral carriage of Candida in the host without any systemic disorders and to reveal predisposing factors associated with virulence of Candida in young adults. Samples were collected from oral cavity in 108 students attending the School of Life Dentistry at Niigata, The Nippon Dental University. Average age of subjectives was 23.5 years old and 81 males and 27 females in gender. Before examination, questionairs were corrected concerning to daily mediation or complication of systemic disorders to exclude from healthy groups. Yeasts were isolated according to CHROMagar method and identified using a combination of the API 32C AUX yeast system. Result of 33 examined from 108 subjectives were Candida positive and positive rate was $30.6 \%$ respectively. Thirty-three identified species were all Candida albicans and 1 Candida glabrata was simultaneously identified from the same sample judged by mean of CHROMagar. Different host factors were analyzed statistically to establish their importance as predisposing factors to allow Candida colonization. However, relationship between isolation rate of Candida and loss of salivary flow rates was remarked. These results suggest that oral yeast status may be influenced by salivary flow rates.
\end{abstract}

Key words : Candida, healthy control, oral candidiasis, salivary flow rate

\section{Introduction}

Candida is a fungus that is an indigenous organism in the oral cavity and widely colonizes the gastrointestinal tract. It is not pathogenic under general conditions, but can be a cause of so-called opportunistic infection in which a variety of infections may arise when the host protection is weakened. Candidiasis, particularly arises in the oral cavity, larynx, and esophagus, in the patients with immunocompromised states associated with diabetes mullitus, chronic renal failure, liver cirrhosis, HIV infection, and organ transplant. Also, it is well known that long-term administration of antibiotics, anticancer drugs,steroids, and immunosuppressants at the time of organ transplantation often effect to grow Candida. As local factors of salivary secretion and poor management of oral hygiene may effect more Candida colonalization ${ }^{1)}$.

On the other hand, regarding the criteria of oral candidiasis cannot be attained even if fungi was confirmed by culture or histological investigation. The clinical definition of oral candidiasis has reported as "a lesion that is

Department of Oral and Maxillofacial Surgery, School of Life Dentistry at Niigata, The Nippon Dental University

(Chief: Prof. Izumi MatAGA)

〔Received September 14, 2010 : Accepted November 30, 2012〕 associated with white plaques and can be removed by scratching, which later develops pain or exposes a hemorrhagic surface" ${ }^{22}$. Clinical findings are currently a prerequisite for the diagnosis of oral candidosis.

The detection rate of Candida, an indigenous organism in the oral cavity, has been reported to range widely from $1.9 \%-62.3 \%$ in healthy adults ${ }^{3)}$. The reasons for the large variation in the frequency include not only the methods to collect, isolate, and identify fungi, but also age, complications, conditions at the time of collecting the sample, and the oral hygiene conditions of the host to be examined. Virulence of Candida remains unclear even though biological types and capacity of protease and phospholipase production have been investigated.

In this study, we examined the detection rates of Candida from the oral cavity and numerous factors of oral hygiene conditions that were assumed to be related with the onset of candidiasis in healthy volunteer students in our school.

\section{Subjects and Methods}

The subjects were composed of 108 (81 males and 27 females) 5th-grade undergraduate students of School of Life Dentistry at Niigata, The Nippon Dental University, aged from 22 to 27 years with an average age of 23.5 
years, who gave their informed consent to the study. The subjects were healthy adults without any underlying disease in the past or at present, who did not have inflammatory changes in the mucosa such as white lesions, white coats, and stomatitis by oral examination, which would indicate oral candidiasis.

Parameters were assessed as follows: Oral hygiene conditions (presence or absence of tartar on teeth and dental caries, brushing before sample collection, and the use of a collutorium) were examined at the time of sample collection, and life style habits such as alcohol drinking and smoking, and general conditions were surveyed, in addition to the examination of the amount and appearance of saliva.

In principle, samples were collected at a fixed time, 1400 hours. The subjects had not been informed of the collection. TRANSWAB ${ }^{\circledR}$, a cotton swab, was used to collect the samples. Samples were collected from the dorsum of the tongue for examination. For isolation and identification of Candida, the CHROMagar culture medium (Kanto Kagaku K.K., Japan) ${ }^{4)}$ was used because it provides high reproducibility. After 48 hours of culture at $37^{\circ} \mathrm{C}$, fungus species was identified on the basis of the color of the colony and the presence or absence of thick film spores, with the API code (API32C AUX, Japan Biomeryun, Co.). In addition, one colony was collected from each case and cultured on Sabouraud-glucose agar medium for 48 hours at $42^{\circ} \mathrm{C}$, and subjected to a screening test in parallel with the comparison with the standard strain of Candida dubliniensis (C. dubliniensis) in terms of morphology of thick film spores.

Salivary secretion rate was examined by resting whole saliva method for 10 minutes and total amount of salivary flow rate of $1 \mathrm{ml}$ or less in $10 \mathrm{~min}$ was designated as decreased resting salivary secretion and performed Saxon test according to regular method and less than $2.00 \mathrm{~g}$ is usually judged as decreased stimulated salivary secretion.

The Saxon test was administered first with a gauze sponge $(5 \times 5 \mathrm{~cm})$. Saliva was collected by having the patients chew the gauze for 2 minutes. The amount of salivary secretion was determined by measuring the increased weight of the gauze after chewing. Total number of Candida colonies were counted from whole field of cultured plates.

The study was approved in advance by the ethical committee of School of Life Dentistry at Niigata, the Nip-
Table 1 Species distribution of 33 subjects with Candida colonization

\begin{tabular}{cc}
\hline Candida species & Number of subjects \\
\hline C. albicans alone & 31 \\
C. glabrata + C. albicans & 1 \\
C. albicans + C. krusei suspected & 1 \\
\hline total & 33 \\
\hline
\end{tabular}

pon Dentistry University, and informed consent was obtained after the contents of the study were fully explained to the subjects. Statistical analysis was performed by the $\chi^{2}$ test for comparison between the two groups.

\section{Results}

Candida was isolated from the oral cavity in 33 of 108 cases. Positive ratio was $30.6 \%$. Of these, Candida albicans (C. albicans) was most frequently isolated in all 33 cases. In one case, C. albicans and C. glabrata were both found. C. krusei was suspected from the culture on the CHROMagar Candida medium but the species was not determined by the API. C. dubliniensis was not detected in this screening (Table 1).

As for the relation between clinical factors which will be effected the detection such as gender and the detection of Candida, it was isolated in 13 of 81 males (28.3\%) and 10 of 27 females (37.0\%), indicating that Candida was isolated slightly more frequently in females. There was no statistical difference between gender and the detection rate of Candida. As for the relation between smoking and the detection of Candida, it was isolated in 19 of 52 smokers (36.5\%) and 14 of 56 non-smokers (25.0\%), indicating that it was detected more frequently in smokers, but there was no significant difference.

As for the relation between drinking habits and the detection of Candida, it was detected in 19 of 62 drinkers (30.6\%) and 14 of 46 non-drinkers (30.4\%), and it was detected almost similarly in the two groups. In terms of the relation between the presence of a dental cavity and the detection of Candida, it was detected in 17 or 60 (28.3\%) cases with a dental cavity that had not been treated or was being treated, and in 16 of 48 (33.3\%) cases without a dental cavity. The detection rate was lower in the cases with a dental cavity than in those without it, but there was no statistical difference. When 
Table 2 Clinical factors and oral Candida carriage

\begin{tabular}{|c|c|c|c|c|}
\hline & & Can. (+) & Can. $(-)$ & total \\
\hline \multirow{2}{*}{ gender } & male & 23 & 58 & 81 \\
\hline & female & 10 & 17 & 27 \\
\hline \multirow{2}{*}{ smoking } & smoker & 19 & 33 & 52 \\
\hline & non-smoker & 14 & 42 & 56 \\
\hline \multirow{2}{*}{ alcohol } & drinking & 19 & 43 & 62 \\
\hline & non-drinker & 14 & 32 & 46 \\
\hline \multirow{2}{*}{ tooth } & dental caries & 17 & 43 & 60 \\
\hline & without caries & 16 & 32 & 48 \\
\hline \multirow{2}{*}{ brushing } & brushing & 13 & 30 & 43 \\
\hline & non-brushing & 20 & 45 & 65 \\
\hline \multirow{2}{*}{ dental calculus } & tartar & 11 & 29 & 40 \\
\hline & non-tartar & 22 & 46 & 68 \\
\hline
\end{tabular}

Can.(+): Candida carriers, Can. ( - ): Candida non-carriers

Statistic analysis: all N.S.

Table 3 Relationship between salivary secretion and oral Candida carriage

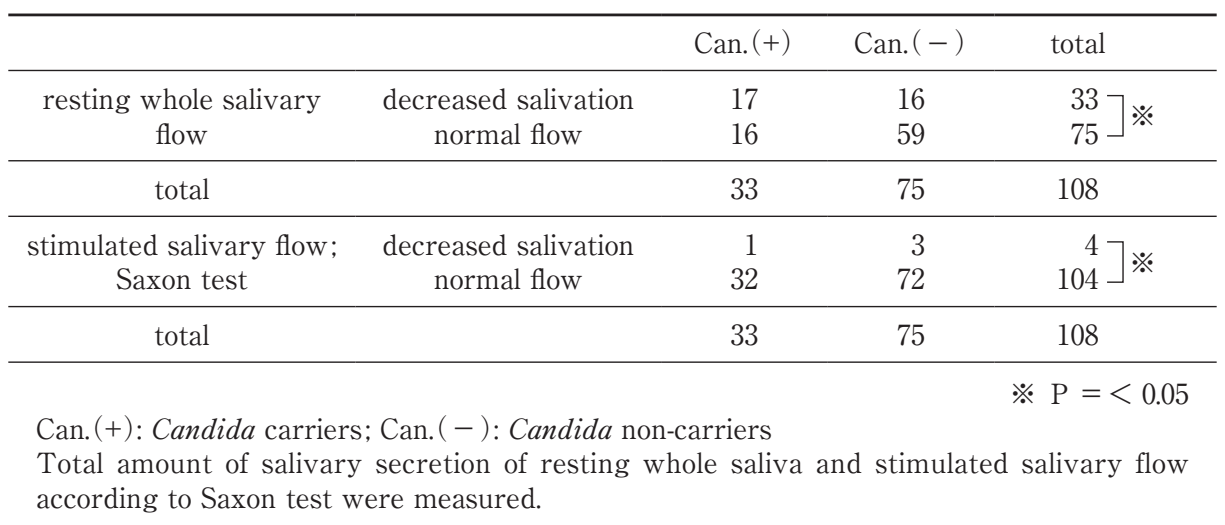

it comes to the relation between tooth brushing before sample collection and the detection of Candida, it was detected in 13 of 33 (39.3\%) cases with tooth brushing before lunch and 20 of 75 (26.7\%) cases without it, yielding no statistical difference. With regard to the relation between tartar on teeth and the detection of Candida, it was detected in 11 of 40 (27.5\%) cases with tartar on teeth and more frequently in 22 of 65 (33.8\%) cases without it, but there was no significant difference (Table 2).

For comparison between the amount of saliva secretion and the detection of Candida, the amount of whole saliva at rest was examined. When the amount of saliva secretion $1 \mathrm{ml}$ or less in 10 min was designated as decreased saliva secretion, 33 of 108 (30.8\%) cases showed decreased saliva secretion, and Candida was detected in as many as 17 cases $(51.5 \%)$. On the other hand, in cas- es with the amount of whole saliva secretion at rest $2 \mathrm{ml}$ or more in $10 \mathrm{~min}$, which was judged as normal, Candida was detected only in 16 of 75 cases (21.3\%). Intriguingly, the detection rates of Candida were dependent on the amount of saliva secretion even in the healthy subjects. When the amount of whole saliva secretion was normal, the Saxon test revealed normal values $(2.0 \mathrm{~g} / 2 \mathrm{~min}$ or more), and the Duotest ${ }^{\circledR}$ showed $\mathrm{pH}$ of saliva ranging from 6.5 to 7.5 (Table 3). Then, in 33 cases in which Candida was detected, the amount of saliva secretion at rest and the amount by the Saxon test were not associated with the number of colonies on the culture plate.

The numbers of Candida colony-forming unit (CFU) counted on the cultured plate were respectively deviced two groups,less than 10,000 and more than 10,000 among cultured positive 33 subjects. The former was 26 (78.8\%) 


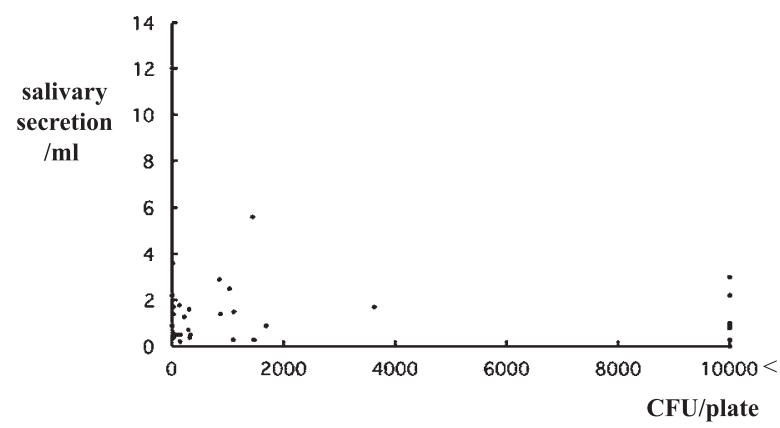

Fig. 1 Relationship between the amount of salivary secretion and the number of colonies on the culture plate.

CFU: Candida colony-forming unit

and later was 7. Significant correlation between the number of colony forming and the amount of resting salivary flow or stimulated salivary flow measured by Saxon test were observed (Fig. 1, 2).

\section{Discussion}

Candida species comprises about 150 kinds of fungi, and nine types, represented by C. albicans, cause candidiasis $^{5)}$. Of the Candida yeasts isolated from the oral cavity, C. albicans has been reported to be the most frequently isolated in $60-80 \%$, followed by $C$. tropicalis and C. glabrata $^{5}$. Hyphae and pseudohyphae of the Candida species have been reported to be detected from the dorsum of the tongue in $16.7-36.0 \%$ in healthy subjects, and detection of the fungi by culture and the diagnosis of oral candidiasis based on the fungal type by microscopic examination have recently been considered impossible ${ }^{6-8)}$. In addition, management of oral hygiene has been reported to be associated with the detection of Candida in the oral cavity, and in terms of the location except for artificial denture, the detection rate tended to be higher at the root of the tongue ${ }^{9}$.

Previous studies on the detection rate of Candida in healthy adults were mostly performed in subjects with a wide age range irrespective of oral hygiene status ${ }^{5,10)}$. Detection rates of Candida in general healthy subjects range widely from $9.9 \%$ to $60 \%$ or higher. Kato et al. ${ }^{11}$ reported that $C$. albicans was isolated from the tongue in 16 of $162(9.9 \%)$ subjects aged 60 years or younger. Shin $e t a l .{ }^{12)}$ reported that the detection rate of Candida by three methods of sample collection using saliva and gargling, was $45.0 \%$ in 118 young healthy subjects aged 20-39 years (24.7 years on average). Furthermore, Ne-

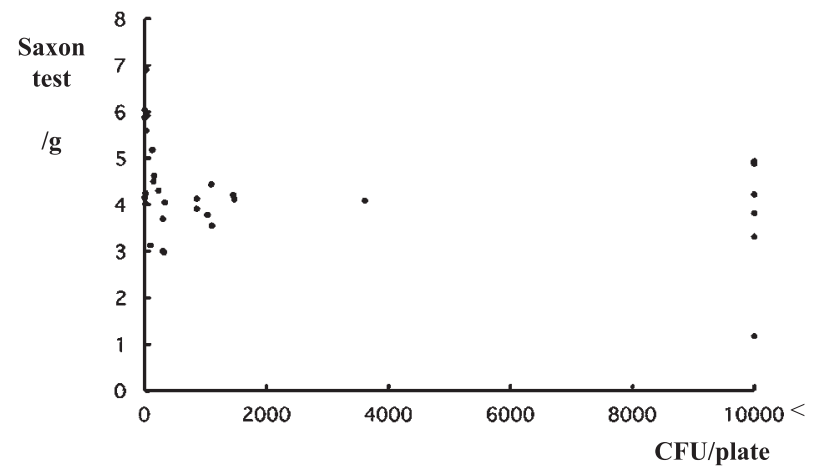

Fig. 2 Relationship between the Saxon test and the number of colonies on the culture plate. CFU: Candida colony-forming unit

groni, et al. ${ }^{13)}$ reported that the detection rate by the swab from the tongue was $21.4 \%$ in 70 young healthy subjects aged 23 years on average ${ }^{12)}$. Both studies were conducted on dentistry college students, and when they did not have artificial denture or underlying disease, they were designated as healthy subjects. In the present study, the subjects ranged from 22 to 27 years with 23.5 years on average, and they did not have apparent periodontal disease or artificial denture.

In terms of detection methods, direct microscopic examination detected fungal hyphae and pseudohyphae from the dorsum of the tongue in healthy subjects in a wide range of $16.7 \%$ to $36 \% 3,7,8,14$. Swab culture from the tongue mucosa detected Candida in $42.9 \%$ to $56.4 \%$, higher than direct microscopic examination ${ }^{15,16)}$. With respect to disease, Kohno et al. ${ }^{17)}$ reported that yeast-like fungi were detected in $60.6 \%$ of the patients with a pain in the tongue, of which C. albicans was found in $48.5 \%$. In addition, culture provided the detection rate of $21.8 \%$ in healthy subjects and a more significantly higher rate of $56.4 \%$ in patients with a pain in the tongue. Lucas ${ }^{18)}$ reported that Candida was isolated in 30\% of healthy subjects similarly by culture. Arendorf et $a l .{ }^{7)}$ mentioned that even in the same healthy subject, the detection rate was dependent on the location of sample collection, being $31.5 \%$ at the back of the tongue and $16.7 \%$ at the front of the tongue. This difference due to the location may be ascribed to the fact that mobility of the tongue is larger and self-cleansing and cleaning are higher at the front.

As for the detection rates in different gender, according to the report comparing the patients visiting the dental clinic by Masipa et al. ${ }^{19)}$, Candida was detected in 
$44 \%$ of males and $61 \%$ of females, and more frequently found in females. Also in the present study, it was detected in 10 of $27(37.0 \%)$ females and 13 of 81 (28.3\%) males, and it was isolated more frequently in females, but there was no statistical difference between the two.

As Candida species isolated from the oral cavity, C. albicans accounted for the predominance by as much as 60-80\%, followed by C. tropicalis and C. glabrata at $6-7 \%{ }^{7)}$. Recently, C. dubliniensis was reported to be closely associated with HIV infection ${ }^{12}$, but there have been no such reports in Japan. In the present study, $C$. albicans was found in all 33 cases, consistent with the previous reports, which implicates that C. albicans is the important fungus responsible for opportunistic infection of oral candidiasis.

The relation between smoking and oral hygiene factors such as oral cavities and dental calculus has yet to be clarified. Arendorf et al. ${ }^{20)}$ reported that Candida was detected highly in smokers, but other reports failed to show the evidence of a remarkable relation ${ }^{21,22)}$. Furthermore, it was reported that dental calculus was not important for the colonization of Candida and the Plaque Index had little impact on the detection rate ${ }^{22,23)}$. However, in a report with HIV-infected patients, smoking and oral hygiene factors increased the detection rate of Can$\operatorname{did} a^{22)}$. In the present study, Candida was detected in 19 of $52(36.5 \%)$ smokers, more frequently than in 14 of 56 (25.0\%) non-smokers.

As for brushing after meals, Candida was detected in 13 of $33(39.3 \%)$ cases with brushing and 20 of 75 (26.7\%) cases without it, yielding no significant difference between the two. With regard to the dental calculus associated with periodontal disease, Candida was found in 11 of 40 (27.5\%) cases with deposition of dental calculus, unexpectedly, less frequently than in 22 of 65 (33.8\%) cases without it, but there was no statistical difference.

In terms of the relation with dental caries, Fosdick et $a l .{ }^{24)}$ reported that yeast played a major role in the progress of dental caries in vitro. In their experiment, some types of yeast in the oral cavity showed higher acid productivity than Lactobacillus. Early clinical findings indicated that Candida in the saliva was involved in the advancement of oral cavities. These results have been confirmed by similar studies ${ }^{25,26)}$, while opposite results have also been reported. Recently, Shen et al. ${ }^{28)}$ reported that Candida was isolated frequently from root sur- face caries. In the present study, it was detected in 17 of $60(28.3 \%)$ cases with untreated teeth or teeth under treatment and in 16 of $48(33.3 \%)$ cases without such teeth.

With respect to the relation with drinking habits, Tillonen et al. ${ }^{29)}$ found that Candida played a critical role in the production of acetaldehyde in a study examining the relation between acetaldehyde concentrations in the saliva and cancer in the oral cavity, and reported that Candida was frequently detected in those with a drinking habit. In the present study, it was detected in 19 of 62 (30.6\%) in cases with a drinking habit and 14 of 46 (30.4\%) in cases without it, yielding no statistical difference.

Broad range antibiotics and steroids have been regarded as iatrogenic causes of oral candidiasis. They render the host immunocompromised and induce a microbial substitution, leading to the candidiasis-prone status ${ }^{5)}$. In the current study, as for the causal relation with oral medicines such as antibiotics, Candida was detected in 2 of $5(40.0 \%)$ cases in which oral medicine had been taken within two weeks before the sample collection. In these two cases, cephem antibiotics and steroids were taken in combination for a common cold and bronchial asthma, and microbial substitution was diagnosed. Recently, as is the case with allergic bronchopulmonary aspergillosis, atopic predisposition is a risk factor of Asperigillus infection $^{30)}$. Then, detection of Candida and host allergic disease were questioned, and Candida was detected in 8 of $24(33.3 \%)$ cases with atopic dermatitis and asthma, slightly more frequently in 25 of 84 (29.8\%) cases without such diseases, but there was no significant difference.

Negroni et al. ${ }^{13)}$ reported that Candida was frequently detected in the cases using a collutorium, which was thought to influence indigenous bacterial flora in the oral cavity. In the present study, Candida was found in 4 of $10(40.0 \%)$ cases using a collutorium and in 29 of 98 (29.6\%) cases not using it. The reason why Candida was detected more frequently in cases using a collutorium was presumed to be that the number of cases was only 10, which would provide low reproducibility, and a collutorium was used in combination with antibiotics.

Previously, the amount of saliva was reported to be related with Candida infection ${ }^{31,32}$. In immunocompromised hosts and subjects with impaired immune responses, the amount of saliva and the detection of Candida were associated, and more Candida colonies were detect- 
ed in patients with a dry mouth ${ }^{31)}$.

By contrast, the amount of saliva at rest was reported to have no relation to the detection of Candida in healthy subjects $^{12)}$, but the relation with the colony number was not shown. In the present study, although saliva was collected by the spitting method, the detection rate of Candida and the amount of saliva at rest were compared, and there was a significant correlation between the detection rate and the group with reduced saliva secretion as low as $2 \mathrm{ml}$ or less in $10 \mathrm{~min}$. Measurement of saliva secretion by the Saxon test and the saliva $\mathrm{pH}$ monitoring by the Duotest revealed that most cases showed results within normal limits.

In 33 cases in which Candida was detected, the number of colonies on the plate had no association with the amount of saliva at rest or the results by the Saxon test. Saliva contains antibacterial substances such as lysozyme, histatin, and lactoferrin, and they decrease as saliva secretion decreases. Microorganisms in the oral cavity are always washed away by saliva. Colonization of Candida was accelerated by decreased saliva flow, decreased $\mathrm{pH}$, and increased glucose concentrations in the saliva $^{33)}$.

Taken together, in the present study on healthy subjects, the amount of whole saliva at rest strongly correlated with the detection of Candida, but other factors had no significant correlation. Shin et $a l .{ }^{12)}$ examined saliva by collecting it directly or the gargling method. Since these are different from the Swab method, it is possible that a difference in the detection rate and the types of isolated organisms might be produced. It is necessary to compare the detection rates with the collection method in the future. In addition, the variation of the carrier rate was thought to be ascribable to the difference in the subject groups and sample collection methods ${ }^{34)}$. Candi$d a$ was detected in one third of healthy subjects, and it is necessary to explore the mechanisms of how it colonizes the oral mucosa and develops symptoms.

\section{Conclusions}

Detection rates of Candida in 108 healthy adults were compared with oral hygiene and parameters that might induce the onset. The conclusions are as follows:

1. Candida was detected in the oral cavity in 33 of $108(30.6 \%)$ cases, and C. albicans was detected in all cases. For its isolation, CHROMagar was useful.

2. As for gender, Candida was detected in 10 of 27
(37.0\%) females, more frequently than in 13 of 81 (28.3\%) males.

3. Detection rates of $C$. albicans had no significant correlation with gender, oral hygiene, lifestyle habits such as alcohol drinking and smoking, or the presence or absence of allergy.

4. In terms of the amount of saliva secretion, the amount of whole saliva secretion at rest negatively correlated with the detection rate of Candida, and as the amount of whole saliva secretion at rest decreased, the detection rate of Candida tended to increase.

5. The colony number of Candida by the sterilized cotton swab test had no significant correlation with the amount of salivary flow at rest or stimulated salivary flow resulted by the Saxon test.

\section{Acknowledgements}

We deeply thank Emeritus Professor AOKI Shigeji, Advanced Research Center, School of Life Dentistry at Niigata, the Nippon Dental University, for his valuable advices and instructions. In addition, we thank staff members of the Department of Oral and Maxillofacial Surgery, and the fifth grade undergraduate students in School of Life Dentistry at Niigata, the Nippon Dental University.

\section{References}

1) Odds FC: Candida and candidosis: a review and bibliography. Bailliere Tindale, London, 1998, pp. 1-123.

2) Basker SN: Synopsis of Oral Pathology, Mosby C.V.Comp., Saint Louis, 5th ed., 1977, pp. 374-376.

3) Wright BA and Fenwick F: Candidiasis and atrophic tongue lesions. Oral Surg $51: 55-61,1981$.

4) Kohda $M$ : Isolation and selection on the significance of CHROMagar Candida. Clin Microbiol 23 : 235-243, 1996.

5) Yamaguchi H: Candida infected disease: Pathogenesis and fungal. Nanzan-doPublisher, 1999, pp. 92-99.

6) Odds FC: Ecology of Candida and epidemiology of candidosis, in Candida and Candidosis. 2nd ed., Balliere Tindall, London, 1989, pp. 68-116.

7) Arendorf TM and Walker DM: The prevalence and intra oral distribution of C. albicans in man. Archs Oral Biol 25 : $110,1980$.

8) Rindum JL: Indentification of $C$. albicans types related to healthy and pathological oral mucosa. J oral Pathol Med $23:$ 406-412, 1994.

9) Maki Y: Support of oral care in hospitalized patients at psycosomatic center, Part 3, Relation between detection of Candida and oral hygiene. J Dent Health $50: 656-657,2000$.

10) Fukushima K: Candidosis:Kinbara-Publication, Tokyo, 1992, pp. 227-238.

11) Kato T, Maruyama $\mathrm{R}$ and Nishioka K: Isolation of Candida albicans from tongue with cutaneous infection diseases. Jpn Derm Associ $108:$ 1433-1436, 1998. 
12) Shin ES, Sung-Chang C, Young-Ku K, et al: The relationship between oral Candida carriage and the secretor status of blood group antigens in saliva. Oral Surg Oral Med Oral Pathol Oral Radio Oral Endod 96 : 48-53, 2003.

13) Negroni M, Gonzalez MI, Levin B, et al: Candida carriage oral mucosa of a student population: adhesiveness of strains and predisposing factor. Rev Argent Microviol $34: 22-28$, 2002.

14) Ando T, Kaneko Y, Yamasaki T, et al: Relatioship between Candida and burning tongue. Jpn J Oral Diag $14: 368-371$, 2001.

15) Gorsky M, Silverman S, Chinn H: Burning mouth syndrome: a review of 98 cases. J Oral Med 42:7-9, 1987.

16) Holbrook WP and Rodgers GD: Candidal infections: experience in a British dental hospital. Oral Surg Oral Med Oral Pathol 49 : 122-125, 1980.

17) Kohno $\mathrm{K}$ and Yanagisawa S: Candida albicans in burn tongue and relationship between efficacy of antifungal drugs. Jpn J Oral Mucosa 6:56-61, 2000.

18) Lucas VS: Association of psychotropic drugs, prevalence of denture-related stomatitis and oral candidosis. Community Dent Oral Epidemiol 21 : 313-316, 1993.

19) Masipa JN, Human $\mathrm{CH}$ and Raubenheimer EJ: Oral carriage of candida species in patients visiting the Medunsa Dental Clinic. J Dent Assoc S Afr 47 : 407-409, 1992.

20) Arendorf TM, Walker DM: Denture stomatitis: a review. J Oral Rehabil $14: 217-227,1987$.

21) Willis AM, Coulter WA, Fulton CR, et al: Oral candidal carriage in Sjögren's syndrome patients with healthy xerostomic controls. Diab Med 16 : 675-679, 1999.

22) Scully C, EL-Kabir M and Samaranayake LP: Candida and oral candidosis: a review. Crit Rev Oral Biol Med $5: 125^{-}$ 127, 1994.

23) Cannon RD, Holems AR, Mason AB, et al: Oral Candida clearance, colonization,or candidiasis. J Dent Res $74: 1152-$ 1161, 1995.

24) Fosdick LS and Hansen HL: Theoretical considerations of carbohydrate degradation in relation to dental caries. J Am Dent Assoc 23 : 401-407, 1936.

25) Krasse B: The relationship between Lactobacilli, Candida and Streptococci and dental caries. Examination of saliva and plaque material collected on the same occasion. Odontol Revy 5 : 241-261, 1954.

26) Glass RL: The occurrence of yeasts in the saliva chirldren. J Dent Res 30:468, 1951.

27) Kinghton H: A study of monilia and other yeast like organisms found in the oral cavity. J Dent Res 18: 103-125, 1939.

28) Shen S, Samaranayake LP, Yip HK, et al: Bacterial and yeast flora of root surface caries in elderly, ethnic chinese. Oral Dis $8: 207-217,2002$.

29) Tillonen J, Homman N, Rautio M, et al: Role of yeasts in the salivary acetaldehyde production from ethanol among risk groups for ethanol-associated oral cavity cancer. Alchol clin Exp Res $23:$ 1409-1415, 1999.

30) St Leger RJ, Screen SE and Shams PB: Lack of host specialization in Aspergillus flavus. Appl Environ Microbiol 66 : 320-324, 2000.

31) Torres SR, Peixoto CB, Caldas DM, et al: Relationship between salivary flow rates and Candida counts in subjects with xerostomia. Oral Surg Oral Med Oral Pathol Oral Radiol Endod $93:$ 149-154, 2002.

32) Navazesh M, Wood GJ, Brightman VJ: Relationship between salivary flow rates and Candida albicans counts. Oral Surg Oral Med Oral Pathol Oral Radiol Endod 80 : 284-288, 1995.

33) Niimi $M$ and Niimi K: Oral candidosis; basic and clinical problems. The Quintessence 20 : 1603-1612, 2001.

34) Sherman RG, Prusinski L, Ravenel MC, et al: Oral candidosis. Quintessence Int $33: 521-532,2002$.

Reprint requests to Kazunori NinOMIYA, Department of Oral and Maxillofacial Surgery, School of Life Dentistry at Niigata, The Nippon Dental University, 1-8, Hamaura-cho, Chuo-ku, Niigata, 951-8580, Japan 


\title{
健常者口䏶における Candida 保有率の検討
}

\section{梅澤義一 二宮一智又賀泉}

日本歯科大学新潟生命歯学部口腔外科学講座 (主任 : 又賀 泉)

日口内誌, $18: 31 \sim 38,2012$

\begin{abstract}
抄録：カンジダ菌は口腔常在菌の一つでありながら, 健常若年者における頻度に関する研究はなお十分とはいえない。そ こでこの事実に基づいて, 本研究では全身合併症を伴わない健常若年者を対象として, 口腔からのカンジダ菌の検出率と口 腔カンジダ症に関与すると考えられる複数の口腔環境因子との関係を明らかにすることを目的とした。研究対象は, 同意の 得られた日本歯科大学新潟生命歯学部に通学する学生 108 名で, 平均年齢は 23.5 歳, 男性 81 名, 女性 27 名である。検査 を行う前に現在の投与薬㧍よび全身合併症の有無について除外を目的に質問をおこなった。菌の分離培養にはクロモアガー 培地を用い, API32C AUXにて菌を同定した。その結果, 口腔から 108 名のうち 33 名にカンジダ菌が検出され, 検出率は $30.6 \%$ でった。検出された 33 名の菌種はCandida albicans が最も多く全例で検出され，1例は Candida glabrata が同時 にクロモアガー培地から検出された。カンジダ菌の増殖に関与すると思われる異なる口腔環境因子とカンジダ菌検出頻度と の間に統計学的有意差は得られなかった。しかし唾液分泌量のうち安静時混合垂液量の低下とカンジダ菌の検出頻度との関 係は有意であった。これらの結果，唾液分泌量はカンジダ菌の増殖に関与すると考えられた。
\end{abstract}

キーワード：カンジダ, 健常人, 口腔カンジダ症, 唾液分泌量

$$
\begin{gathered}
\text { 別冊請求先: 二宮一智 } \bar{\top} 951-8580 \text { 新潟市中央区浜浦町 1-8 } \\
\text { 日本歯科大学新潟生命歯学部口胫外科学講座 }
\end{gathered}
$$

〔受付： 2010 年 9 月 14 日, 受理：2012 年 11 月 30 日〕 